\title{
Digital Transformation of Additional Professional Education: Features of the LK-14 Educational Platform
}

\section{Transformación digital de la educación profesional adicional: características de la plataforma educativa LK-14}

\author{
Galina I. Alekseeva* \\ S.N. Donsky-II Institute for Education Development and Advanced Training, Yakutsk, Russia
} ORCID: https://orcid.org/0000-0002-8946-5087

\section{Olga I. Mikhaleva}

S.N. Donsky-II Institute for Education Development and Advanced Training, Yakutsk, Russia ORCID: https://orcid.org/0000-0003-2827-4428

\section{Vladimir P. Barakhsanov}

M.K. Ammosov North-Eastern Federal University, Yakutsk, Russia

ORCID: https://orcid.org/0000-0003-2054-2555

\section{Dianida G. Abramova}

S.N. Donsky-II Institute for Education Development and Advanced Training, Yakutsk, Russia ORCID: https://orcid.org/0000-0002-7779-6612

\section{Nurgun M. Pavlov}

S.N. Donsky-II Institute for Education Development and Advanced Training, Yakutsk, Russia ORCID: https://orcid.org/0000-0002-3114-9401

Received 07-12-20 Revised 08-04-20 Accepted 08-30-20 On line 09-15-20

*Correspondence

Email: galinaialekseeva@bk.ru
Cite as:

\footnotetext{
Alekseeva, G.I., Mikhaleva, O.I., Barakhsanov, V.P., Abramova, D.G., \& Pavlov, N.M. (2020). Digital Transformation of Additional Professional Education: Features of the LK-14 Educational Platform. Propósitos y Representaciones, $\quad 8(3), \quad$ e699. doi: http://dx.doi.org/10.20511/pyr2020.v8nSPE3.699
} 


\section{Summary}

This article substantiates the relevance of the transformation of the educational environment of additional professional education (APE) in the Republic of Sakha (Yakutia). This study aims to justify the transformation of the educational environment of APE in the context of digitalization and to consider the prospects for targeted professional development of teachers in the republic according to their needs. The authors chose this scientific topic due to the pressing needs of Russian continuing professional education (CPE) and current problems such as the lack of unified approaches and mechanisms for regulating the professional development of teachers in the digital educational environment and the lack of methods for monitoring the effectiveness and efficiency of CPE distance learning programs. Creating an innovative and dynamic CPE system requires the intensive introduction of information technologies into education. These technologies ensure that the learning process is open and of high quality, as well as provide access to global educational resources. This helps learners create "their own individual educational environment" reflecting their needs and requirements. The research methods used to explore this problem were a pedagogical experiment, the analysis of the organization of CPE of teachers in the region, designing a regional model of targeted personalized training of educators and administration. The research results include the specifics of APE modernization in the region and the model of targeted personalized training of teachers of the republic. The qualitative novelty of this model stems from the fact that developing teachers' competencies involves identifying gaps in their professional knowledge and building individual learning paths.

Keywords: Additional Professional Education, Digitalization of the Educational Environment, Information Technology, Professional Competence, Professional Development.

\section{Resumen}

Este artículo confirma la relevancia de la transformación del entorno educativo de la educación profesional adicional (APE) en la República de Sakha (Yakutia). Este estudio tiene como objetivo justificar la transformación del entorno educativo de APE en el contexto de la digitalización y considerar las perspectivas de desarrollo profesional dirigido de los docentes en la república de acuerdo con sus necesidades. Los autores eligieron este tema científico debido a las necesidades apremiantes de la educación profesional continua rusa (CPE) y los problemas actuales, como la falta de enfoques y mecanismos unificados para regular el desarrollo profesional de los docentes en el entorno educativo digital y la falta de métodos de monitoreo La efectividad y eficiencia de los programas de educación a distancia CPE La creación de un sistema CPE innovador y dinámico requiere la introducción intensiva de tecnologías de la información en la educación. Estas tecnologías aseguran que el proceso de aprendizaje sea abierto y de alta calidad, y proporcionan acceso a recursos educativos globales. Esto ayuda a los alumnos a crear "su propio entorno educativo individual" que refleja sus necesidades y requisitos. Los métodos de investigación utilizados para explorar este problema fueron un experimento pedagógico, el análisis de la organización de CPE de docentes en la región, el diseño de un modelo regional de capacitación personalizada dirigida de educadores y administración. Los resultados de la investigación incluyen los detalles específicos de la modernización de APE en la región y el modelo de capacitación personalizada dirigida de maestros de la república. La novedad cualitativa de este modelo se deriva del hecho de que desarrollar las competencias de los docentes implica identificar lagunas en su conocimiento profesional y construir caminos de aprendizaje individuales.

Palabras Clave: Educación profesional adicional, Digitalización del entorno educativo, Tecnología de la información, Competencia profesional, Desarrollo profesional. 


\section{Introduction}

Since 1939, the system of additional professional education in the Republic of Sakha (Yakutia) $(\mathrm{RS}(\mathrm{Y}))$ has been developing in accordance with modern socio-economic trends in the republic and as a priority area of the state policy. Its organization does not change greatly, but this system has quite flexible content, which is improved and updated depending on changes in society and education (Rastorgueva, 2014). The high rates of science and technology development and the active introduction of information technologies into education necessitate creating an innovative dynamic environment for the Institute for Education Development and Advanced Training (hereinafter - the Institute) and transforming its organizational forms. Information, communication, as well as audiovisual and interactive technologies are now becoming the basis for a new educational environment, a new media culture of education.

The Decree of the President of the Russian Federation "On national goals and strategic objectives for the development of the Russian Federation for the period up to 2024" and the national project "Education" state that by 2024 the country should:

- Create a modern and safe digital educational environment that ensures high quality and accessibility of education of all types and levels;

- Introduce a national system of professional development, reaching out to at least a half of all school teachers (Decree of the President of the Russian Federation, 2018).

Employers and consumers of educational services can participate in building an effective model of professional development. The active introduction of information technologies into education necessitates constructing a new dynamic environment for additional professional education (Alekseeva, 2016).

At present, in the context of the implemented National System of Teacher Development (NSTD) and the digitalization of the educational environment, the Republic of Sakha (Yakutia) is devising the content of personalized APE programs by monitoring the performance of individual educational organizations, testing teachers, and responding to the diverse demands of the professional community (Alekseeva, 2015).

\section{Literature Review}

The issues related to APE improvement were considered in a number of Russian research papers (Bobeshko, 2016; Kasprzhak, 2007; Kotlyarova, 2008; Mikhaleva \& Abramova, 2019; Sopin, 2014) and international publications (Drucker, 1992; Fischer \& Ostwald, 2001; Dorroh et al., 1994). Many scientists studied the impact of digitalization on the traditional education system, including APE, digital and online learning, and digital competencies of teachers in professional development (Brevik et al., 2019; Brolpito, 2019; Dubey et al., 2019; Mychka \& Shatalov, 2016). Significant attention has been paid to the role of new technologies in knowledge management (Rollete, 2003). The system of APE has some specifics, which are studied by andragogy - the science exploring the methods and principles used in adult education (Knowles, 1980). The creation of different methods of interactive teacher training were considered by some Russian researchers (Akopova, 2004; Abrosimov, 2009; Galkina, 2011; Kovaleva, 2013; Kondakov, 2005). They believe that creating individual learning paths requires a specially organized environment that can meet the following criteria: openness, sufficiency, and variability. Building such an educational environment helps to meet the demand for a personalized system of advanced training and professional retraining. 
The publications of the teaching staff of the North-Eastern Federal University and the Herzen State Pedagogical University published in international journals outline the construction of a new model of teacher training. Along with traditional methods, this model includes innovative educational technologies and tools used during the digitalization of teacher education (Barakhsanova et al., 2017; Barakhsanova et al., 2018; Vlasova, et al., 2018; Vlasova et al., 2019).

Therefore, the transformation of APE implies the application of modern information and communication technologies and the creation of an automated educational platform, as well as an educational environment with active interaction of all the parties of the learning process. Digital transformation of the APE environment requires solving practical problems related to the timely development and updating of relevant educational programs, automatic construction of courses based on the identified level of teachers' competence, and devising individual educational trajectories

\section{Material and Methods}

This research presents the pedagogical experiment carried out at the subject departments of the Institute. This work involved developing and testing a regional system of targeted, personalized system of continuous professional development on an integrated electronic platform "LK-14 New Opportunities." This article describes the practice of using information technologies for creating an innovative and dynamic electronic platform at the Institute. This platform enables a free choice of educational programs and modules for covering the gaps in professional knowledge of teachers.

The LK14 automated system for teacher professional development is an information and software solution used for APE of teachers in the Republic of Sakha (Yakutia). This system includes competence testing and building an individual learning path offline, online, and via selfstudy. In addition, this system incorporates automated document management, maintains electronic databases (feedback), and has personal accounts of all teachers in the republic.

The LK14 system assesses the professional competencies of teachers according to the following characteristics:

- Testing is done online with automated calculation of the result in real time immediately upon the test completion;

- The testing platform supports a wide range of web browsers (Google Chrome, Mozilla, Firefox, Opera, Internet Explorer, Safari and others), mobile devices with Android or iOS operating systems, as well as personal computers running Windows 7 (and above) or MacOs (and above) operating systems;

- User functions include registration, authorization, selecting a test, taking a test, and viewing the result and mistakes;

- The system has a multilingual user web interface and supports characters of all writing systems (Unicode); it can be integrated with Active Directory, 1C: Enterprise or with any information system used at a school;

- Tests have a time limit and can be taken only once;

- The variability of test tasks prevents cheating;

- The types of test tasks vary (for example, matching, choosing one or several correct answers); 
- Teachers have access to their personal test results in their personal account (gaps in knowledge, personal training sessions, or training format);

- Testing data are collected and accumulated in real time, including the data on the number of test participants and the level of tested competencies in different areas.

The testing is done online, with limited time. Its duration depends on the number and difficulty of the questions. There are different types of tasks: selecting one or several correct answers (when one should choose several correct answers, points are subtracted if an incorrect answer is selected). The test assesses several components of teachers' professional competence.

Table 1.

The components of professional competence and target groups

\begin{tabular}{ccc}
\hline No. Components of professional & Target groups \\
competence &
\end{tabular}

1. Subject knowledge Different tests for teachers of Mathematics, Russian

Language and Literature, History, Social Studies, Biology,

Chemistry, Computer Science, and English.

\begin{tabular}{lll}
\hline 2. & Methodology & The same test for all teachers \\
\hline 3. & Psychology and education & The same test for all teachers. \\
\hline 4. & Communicative competence & The same test for all teachers. \\
\hline
\end{tabular}

Teachers get a test on different subjects, while methodological, psychological, pedagogical, communicative competences are assessed with a uniform basic test. The teacher can do the test after logging in their personal account, get the result which identifies their gaps in professional knowledge, and receive recommendations for individual professional development. Testing on subject competence reveals knowledge and skills covered by the school course on the subject.

\section{Results}

The regional model developed aims to ensure the continuous professional and personal development of teachers along an individual learning path. A prerequisite for this is an electronic platform providing educational services of the Institute for targeted monitoring - feedback, personal accounts, counseling, as well as distance and online learning. Personalized advanced training implies that teachers have their own personal account on the Institute's portal, in which, if requested, their gaps in professional knowledge are presented and the information about learning progress is given. Our model is based on the principle of "lifelong learning" and integrates resources on a single platform, offering a free choice of educational programs, individual sequence of their completion with educational outcomes of different levels, thereby contributing to the personal and professional growth of teachers.

The special features of this model are: an ability to choose an additional education program and its mode; active content focused on productive skills; programs are organized in a network and modules; individual and meta-subject content of the programs. 
At present, 19,498 teachers of the republic have registered and have personal accounts on the regional platform "LK-14 New Opportunities." A unified regional database has been created that contains information about educators working in all municipalities and educational organizations, at each position and qualification, with identified gaps in professional knowledge, which are to be eliminated in personalized training programs.

In 2019, we conducted experimental basic testing to assess the professional competencies of the teachers of Mathematics, Russian Language and Literature, History, Social Studies, Biology, Chemistry, Geography, Computer Science, and English to devise individual advanced training programs on this platform. The structure of the tests was different for a particular subject. For example, let us consider the results of the tests of Math and English teachers.

The test for Math teachers consists of 20 questions (with many variations). Each task measures the level of a specific subject competence. Tasks cover five content areas of the school mathematics course. Different topics have the following shares: Probability theory and statistics - 20\%; Algebra - 20\%; Elements of mathematical analysis - 20\%; Planimetry - 20\%; and Stereometry $-20 \%$.

We grouped the results according to the following levels of the tested competencies:

- the red group (insufficient level: below 50\%);

- the yellow group (average level: 50-79\%);

- the green group (high level: $80 \%$ or more).

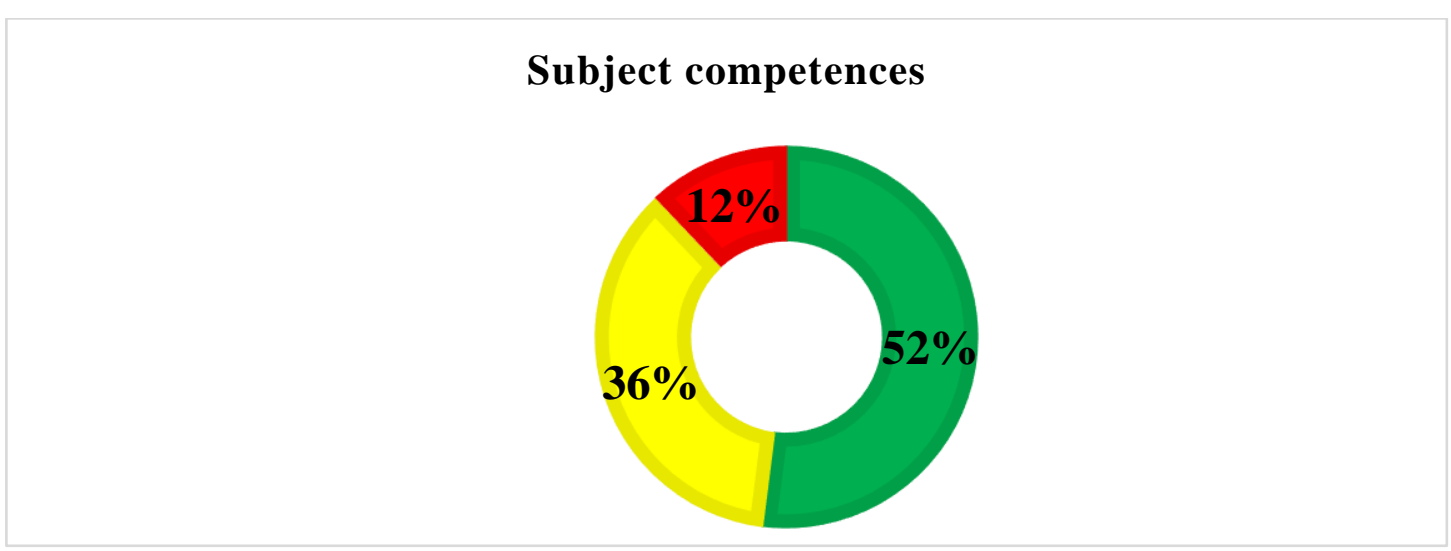

Figure 1. The groups by the levels of the tested competencies.

Having assessed the respondents' professional competencies, we estimated that $12 \%$ of the Math teachers had gaps in subject knowledge, and they needed full-time training with a professional development course. Additionally, $36 \%$ of the teachers had an average level. This demonstrated the need for updating the teachers' knowledge and skills, and mastering new methods and technologies of teaching students. The respondents had difficulty in solving certain problems on probability theory and planimetry. It was hard for them to construct and calculate cross-sectional areas and to solve advanced inequalities and equations. Based on the identified gaps in their knowledge, the system enables teachers to do certain modules of a professional development program to eliminate them. 


\section{Table 2.}

The structure of the test on competencies assessment and the proposed modules of professional development

\section{No Assessed subject competences (gaps in knowledge)}

1. To analyze actual numerical data and statistical information; to do practical calculations using formulas; to do assessment and practical rough calculations.

\section{The corresponding module}

\author{
Module "Mathematical \\ Statistics"- 4 hours.
}

2. To simulate real situations using probability theory and statistics and to calculate the probabilities of simple events.

To solve applied problems, including socio-economic and physical ones, at maximum and minimum values.

Module "Problem solving in probability theory: The classical definition of probability" -2 hours.

3. To simulate real situations using probability theory and statistics. To solve applied problems, including socio-economic and physical ones, at maximum and minimum values.

Module "Problem solving in probability theory: Theorems on the probabilities of events" -4 hours.

4. To simulate real situations using probability theory and statistics and to calculate the probabilities of simple events.

Module "Problem solving in probability theory: Bernoulli's equation" -8 hours.

To solve applied problems, including socio-economic and physical ones, at maximum and minimum values.

5. To solve equations and inequalities containing modules and their systems.

\section{Module "Equations and inequalities containing modules" -4 hours.}

6. To simulate real situations with algebra and to solve equations Module "Word problems" -4 using the apparatus of algebra. hours.

7. To build and explore mathematical models; to solve the simplest Module "Non-standard tasks in non-standard tasks; to use evidence-based reasoning when math lessons" -4 hours. solving problems, to evaluate the logical correctness of reasoning, and to identify logically incorrect reasoning.

\section{To solve advanced equations and inequalities.}

Module "Advanced equations and inequalities" -4 hours.

9. To read a graph to describe the behavior and properties of a function, to find the maximum and minimum values on the

Module "Graphic study of function graph; to plot a graph of the examined functions. functions" -4 hours.

10. To give the geometric and physical interpretation of the derivative in its study.

Module "Geometric and physical interpretation of the derivative" -4 hours. 
11. To draw graphs of the studied functions, to describe their properties, and to solve simple problems containing a parameter.
Module "Study and

construction of advanced functions" -4 hours.

12. To determine rational ways of transforming expressions, to describe the properties of the obtained functions, and to apply an Module "Function study and an antiderivative when solving the areas of figures.

13. To use the basic theorems and formulas of planimetry when solving standard advanced planimetric problems.

Module "Methodology for solving standard advanced planimetric problems" -4 hours.
14. To translate the word statement of a planimetric problem into a geometric drawing, to use the information about the relative position of two or more circles to solve a specific problem.
Module "Methodology for solving problems on the relative position of two or more circles" -4 hours.

15. To give a correct geometric interpretation of the problem, to Module "Methodology for know and to use geometric formulas for inscribed and circumscribed triangles and polygons. solving problems on inscribed and circumscribed circles" -4 hours.

16. To recognize a mathematical problem in the statement, to formulate it as a mathematical problem, to solve a mathematical problem, and to interpret mathematical results in the context of a real situation.

The module "Methodology for solving metasubject problems in planimetry and PISA technology" -6 hours.

17. To use the basic theorems and formulas of stereometry when solving standard stereometric polyhedral problems.

Module "Methodology for solving stereometric problems (polyhedrons)" -4 hours.

18. To use basic theorems and formulas of stereometry when solving standard problems with solids of revolution.

Module "Methodology for solving stereometric problems (solids of revolution)" -4 hours.
19. To translate the word statement of a stereometric problem into a geometric drawing and to use the information about the relative position of two or more stereometric bodies to solve a specific problem.
Module "Methodology for solving stereometric problems on a combination of bodies" 4 hours.
20. To build sections of stereometric figures and to solve the area of the section.

\section{Module "Methodology for solving stereometric problems on sections" -4 hours.}

Tests on the level of English consist of four sections: Use of English, Reading, Grammar, and methodology of teaching English. The tasks are designed in accordance with the requirements of the Common European Framework of Reference for Languages. This classification includes six levels of competence in European languages (A1-C2). The test assignments reflect such levels 
as B2 and C1. Section 4 "Teaching English" covers the main approaches and methods of language teaching. Each section has a list of basic subject competencies, and gaps in these were determined during the testing.

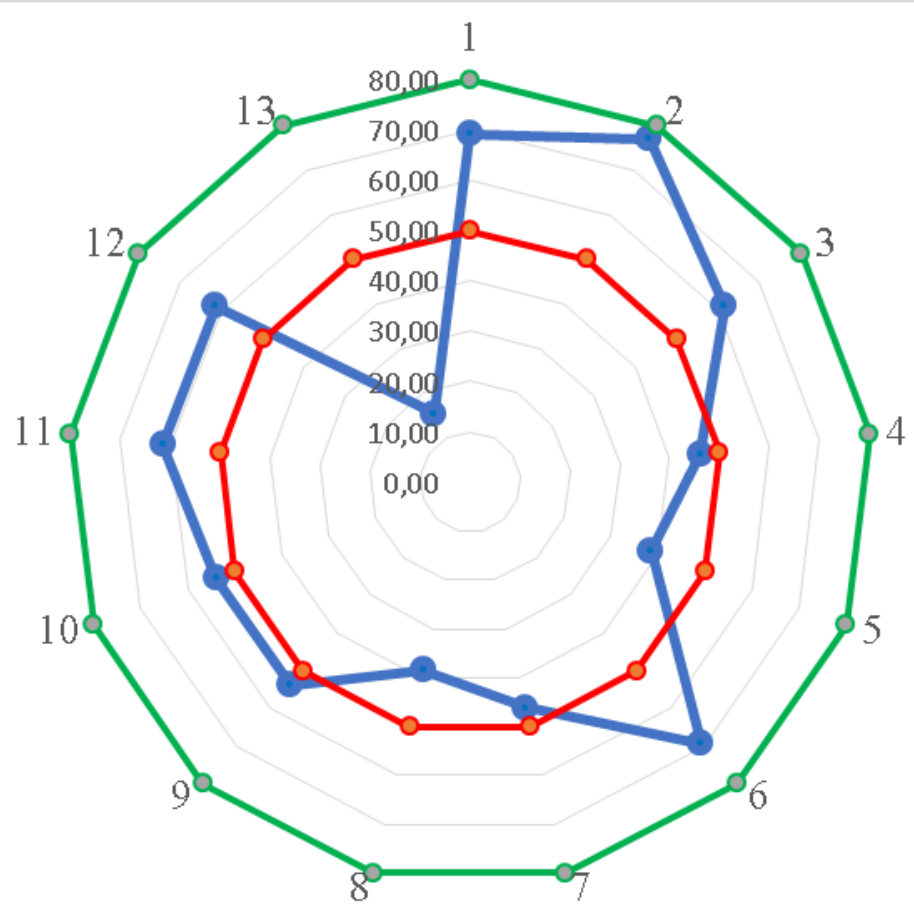

Figure 2. Average result for gaps in subject competencies

Gaps in the subject competencies:

1. Morphology and syntax;

2. Lexis;

3. Grammar;

4. Lesson planning with modern teaching methods;

5. Learning management;

6. Knowledge of the theories and modern methods of teaching a foreign language;

7. Selecting the course content in accordance with the Federal State Educational Standard;

8. Forms and methods of teaching a foreign language;

9. Assessment;

10. Individual learning paths;

11. The content of the Federal State Educational Standard;

12. Modern educational technologies;

13. Modern teaching approaches.

The teachers who did the diagnostic testing demonstrated an average level of subject competencies. The biggest gaps were identified in the section "Teaching English": lesson planning with modern teaching methods, learning management, selecting the content in accordance with the Federal State Educational Standard, the knowledge of forms and methods of teaching a foreign language, as well as mastery of modern teaching approaches. All teachers had developed competencies of the section "Specifics of teaching English." In the language section, $70 \%$ of the participants demonstrated a sufficient level of language proficiency. However, $30 \%$ of the teachers found the Use of English tasks challenging, where they had to fill in the gaps with one of the four options given, and "Reading," which implied working with the text and answering 
the questions about it. Additionally, the teachers demonstrated good results in such competences as the knowledge of the theories and modern methods of teaching a foreign language.

Mastering the proposed programs and modules provides for reaching different learning outcomes. Information technology allows transforming professional development courses that are conducted offline with electronic manuals and video lectures to the format of online classes, online consultations, and educational games.

\section{Discussion}

The first step of taking a personalized course of professional development is the registration of a teacher on the platform. After doing this, teachers can use their own personal account, where they can register for courses online, and also see a detailed schedule. The platform has a filtering function, so that teachers can find the department they need, the subject area, and the field. Next, the system selects courses that meet the criteria indicated.

The platform offers a testing system for four competencies (subject, methodological, psychological and pedagogical, and communicative). Testing can be done in the teacher's personal account. Based on the test results, a teacher is recommended a list of modules and courses aimed at eliminating the gaps in their professional knowledge. A teacher can see the test results for four competencies in the form of diagrams in the dashboard and can choose between two scenarios for an individual route. In the first case, teachers choose a course themselves. In the second case, they receive the system's recommendations based on the identified gaps. At one of the stages, the system appoints a tutor who guides the learner through all the modules.

An important function of the system is the compilation of statistical data that allows one to analyze teachers' professional development. For instance, the system administrator's desktop has information about the number of tests taken, the number of participants by schools and municipal districts, a report on subject tests, the average testing rate for a municipal district, as well as the statistics on the daily number of tests. The system forms a database of the teachers who have passed the test, and three levels of competences are presented as groups of different colors.

The platform can also be useful for making managerial decisions. For example, Table "Report" provides structured information on subjects and all competencies for municipal districts, which allows one to identify problem areas and provide methodological, subject, psychological, pedagogical, and counseling support.

Using the platform, the staff of the Institute monitors the effectiveness of teachers' training through diagnostic procedures and expert assessment. Information technology allows updating the format of professional development courses, so that they can be conducted remotely and online. The courses are organized as a network with internships in educational organizations and support of online instructors. The modular and personalized format of the courses with focus on practical tasks enables each student to actively search for solutions to typical problems arising in their work, which contributes to the formation of their professional and pedagogical competencies.

To date, we have created new modules of educational programs aimed at eliminating gaps in professional knowledge of teachers and increasing their competencies. The developed programs are variable and flexible. Teachers can gradually master different modules, use information and communication technologies, and access electronic educational content for selfeducation. Based on the gaps identified, teachers can choose several modules from the proposed educational programs and design their individual learning path. After testing, teachers can do personalized programs of professional development. 
The advanced training courses allow improving the educational process by enabling the individual to expand their basic knowledge, to enrich their experience, and to master the methods of cognitive, practical, and social activity. Additionally, the developed programs contribute to teachers' creative and social development. Advanced training courses are held online with internships in educational organizations, the guidance of online tutors, in distance and online formats. On the Institute's website and on the platform at boontar.live/sakhaschool/, there is a free resource pack of video lectures, master classes of the best teachers of the Russian Federation, and tele-lessons of the leading teachers of the Republic of Sakha (Yakutia). There are also scientific, methodological, practical and lecture materials, distance courses, and webinars available at the platform.

\section{Conclusion}

The model of teacher professional development in the republic is personalized, which enables educators to choose an educational program that suits them, thus building an individual learning path for advanced training according to their specific needs and gaps in knowledge. This approach allows teachers to play an active role in obtaining lifelong professional education.

The personalized model of advanced training is based on an automated system of objective and comprehensive assessment of school teachers using an integrated electronic platform for advanced training "LK-14 New Opportunities."

We believe that introducing digital technologies into the system of additional professional education facilitates the organization of efficient targeted and personalized training of teachers in the republic according to their needs and gaps in knowledge. What is more, using the LK-14 educational platform during the Lockdown, the Institute could carry out its activities in a distance learning mode.

\section{Acknowledgements}

This article was created as part of the regional project "The Teacher of the Future" of June 18, 2020.

\section{References}

Abrosimov, V. K., Lebidko, V. V. (2009). Individual educational trajectories: Formalization of choice, construction, and management. Open Education, 4(75), 4-16.

Akopova, M. A. (2004). Theory and methodology for the implementation of a personally-oriented approach in the context of selecting additional educational programs. $\mathrm{PhD}$ Thesis (Education). St. Petersburg.

Alekseeva, G. I. (2015). Additional professional education of Yakutia teachers in the context of the Federal State Educational Standard. Public Education of Yakutia, 2, 9-10.

Alekseeva, G. I. (2016). Individually-oriented refresher courses as an imperative of our time. In Modern Additional Professional Pedagogical Education. Network Scientific and Methodological Journal, Special Issue Following the Meeting of Heads of State Organizations Implementing the Programs of Additional Pedagogical Professional Education in the Constituent Entities of the Russian Federation, 3, 21-23.

Barakhsanova, E. A., Varlamova, V. A., Vlasova, E. Z., Nikitina, E. V., Prokopyev, M. S., Myreeva, A. N. (2018). Vocational training of school teachers in Yakutia's universities through the principle of regionalization (case study of the methodology of teaching natural science to prospective teachers). Revista Espacios, 39(20), 35-44. 
Barakhsanova, E. A., Vlasova, E. Z., Golikov, A. I., Kuzin, Z. S., Prokopyev, M. S., Burnachov, A. E. (2017). Peculiarities of quality management of teachers' e-learning training in the Arctic regions. Revista Espacios, 38(55), 25.

Bobeshko, E. V. (2016). Problems of the development of the advanced training system for educators. NovaInfo.Ru, 1(49), 445-449.

Brevik, L. M., Gudmundsdottir, G. B., Lund, A., Strømme, T. A. (2019). Transformative agency in teacher education: Fostering professional digital competence. Teaching and Teacher Education, 86. Article 102875.

Brolpito, A. (2019). Digital Skills and Competence, and Digital and Online Learning. European Training Foundation: Turin.

Decree of the President of the Russian Federation of May 07, 2018 No. 204 "On national goals and strategic objectives of the development of the Russian Federation for the period up to 2024." https://minenergo.gov.ru/view-pdf/11246/84473.

Dorroh, J. R., Gulledge, Th. R., Womer, N. K. (1994). Investment in knowledge: A generalization of learning by experience. Management Science. Providence, 40(8), 947-958.

Drucker, P. (1992). The new society of organizations. Harvard Business Review, SeptemberOctober, 95-104.

Fischer, G., Ostwald, Y. (2001). Knowledge management, promises, realities, and challenges. IEEE Intelligent Systems, 16(1), 60-72.

Galkina, T. E. (2011). A personalized approach in the system of additional professional education for specialists in the social sphere. $\mathrm{PhD}$ Thesis (Education). Moscow.

Kasprzhak, A. G. (2007). Formation of an Innovative Resource of Teaching Staff in the Education System through the Development of an Advanced Training System: A Guidebook. Moscow: Universitetskaya kniga.

Knowles, M. S. (1980). The Modern Practice of Adult Education. From Pedagogy to Andragogy. Englewood Cliffs, NJ: Cambridge Adult Education.

Kondakov, A. M. (2005). Models of educational choice and leading competencies as educational resources for the development of the individual, society, and the state. Izvestia RAO, 1.

Kotlyarova, I. O. (1999). Theoretical Foundations of Personally Oriented Improvement of Professional Pedagogical Qualifications of Educators: PhD Thesis (Education). Chelyabinsk.

Kovaleva, T. M. (2013). Implementation of the tutor model in the system of additional professional education. In Development of the Practice of Tutor Support in Continuing Professional Education. Collection of the Proceedings of the All-Russian ScientificPractical Conference on October 15-16. Arkhangelsk, Publishing House of AO IOO, pp.6-10

Mikhaleva, O. I., Abramova, D. G. (2019). Federal internship platform in the innovative system of professional development: Systemic effects, problems, and prospects. Public Education of Yakutia, 3, 40-43.

Mychka, S. Yu., Shatalov, M. A. (2016). Conducting online lectures (webinars) as part of the strategy for innovative development of education. E-learning in Lifelong Education, 1(3), 1189-1193.

Rastorgueva, N. A. (2014). Pages in the history of Yakutia Republican Institute for Teachers Development: Institute for Education Development and Advanced Training: 1939-2014. Yakutsk: S.N. Donskoy-II IROiPK Press.

Rollete, N. (2003). Knowledge Management: Processes and Technologies. Boston: Klawer Acagemic Publishers.

Vasilenko, N. V. (2009). Education Management: An Institutional Approach. St. Petersburg: GOU IPK SPO.

Vershlovsky, S. G. (1998). Adult Education: Reality, Problems, and Forecast. St. Petersburg.

Vlasova, E. Z., Goncharova, S. V., Barakhsanov, V. P., Ivanova, E. A., Karpova, N. A., Iljina, T. S., Sysoeva, A. S. (2019). Digital transformation of the pedagogical education in the Russian Federation. Dilemas contemporáneos: Educación, Política y Valores, $7(10), 52$. 
Vlasova, E. Z., Goncharova, S., Aksyutin, P., Barakhsanova, E. A., Prokopyev, M. S., Kuzin, Z. (2018). Effective adaptive training of students in Russian pedagogical universities to use e-learning technologies. Revista Espacios, 39, 23. 